\title{
Destructive Fishing Treatment Policy Based on Community Supervision in Lampung Province
}

\author{
Maya Shafira ${ }^{1}$, Mashuril Anwar ${ }^{2}$ \\ \{mayashafira2@gmail.com¹, mashurilanwar97@gmail.com² \\ Faculty of Law University of Lampung, Indonesia ${ }^{12}$
}

\begin{abstract}
The escalation of biodiversity damage has occurred in the Lampung Province sea area along with the increase in capture fisheries production,. This condition is one of them caused by destructive fishing activities. Destructive fishing is still a problem in the sea area of Lampung Province due to the lack of community role, especially in terms of supervision. Tackling destructive fishing based on community supervision is one form of community empowerment to play an active role and directly involved in efforts to combat damage to fishery resources. Therefore, this article discusses the problem of how the condition of the case of destructive fishing in Lampung Province? How are efforts to tackle destructive fishing in Lampung Province? And what is the policy model for controlling community-based destructive fishing? The results showed that from 2016 to 2019, there were 27 cases of the destructive fishery that were tried at the District Court A-Class Tanjung Karang. Efforts in overcoming destructive fishing in Lampung Province have so far tended to be a means of punishment or a repressive action with a criminal law approach. But in fact, this effort has not been able to solve the problem of destructive fishing. Therefore, this research offers a model of destructive fishing management based on community supervision through penal and non-penal means.
\end{abstract}

Keywords: Lampung; destructive fishing; community surveillance

\section{Introduction}

Lampung Province is the southernmost province on the island of Sumatra, well as the gateway to the island of Sumatra that connects with the island of Java. Lampung Province has a large area of sea coast, which is 7 (seven) coastal Regency / City areas. Lampung Province has a land area of $35,288.35 \mathrm{~km} 2$, including 132 small islands around it. The sea area, which covers a distance of 12 nautical miles from the coastline, which is the authority of the waters of Lampung Province, is estimated to be $\pm 24,820 \mathrm{~km} 2$. The strategic geographical location of Lampung Province places Lampung Province as a province with high economic and marine and fishery resources as well as biodiversity and biodiversity.

The geographical condition has used by residents of Lampung, one of which is in the capture fisheries sector in sea waters. Be proven by data from the Ministry of Maritime Affairs and Fisheries, which shows an increase in capture fisheries production in Lampung Province as the following table 1: 
Table 1. Capture fisheries production in Lampung Province 2012-2017

\begin{tabular}{|c|c|}
\hline Year & Production \\
\hline 2012 & 150.342 \\
\hline 2013 & 169.361 \\
\hline 2014 & 164.155 \\
\hline 2015 & 168.943 \\
\hline 2016 & 171.862 \\
\hline 2017 & 178.104 \\
\hline
\end{tabular}

As the increase in capture fisheries production, escalation of biodiversity damage occurs at sea, including in Lampung Province. The strategic geographic location makes the waters of Lampung Province vulnerable to various forms of violations, one of which is destructive fishing. The vulnerability of the seas of Lampung Province described in the figure below:

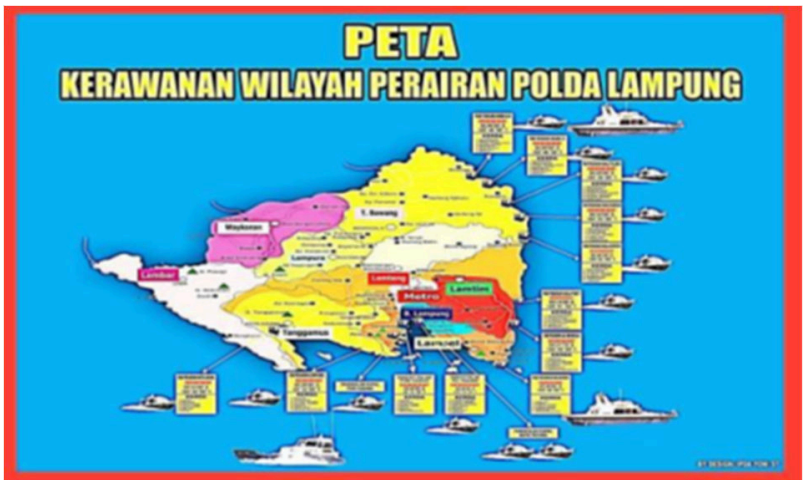

Fig 1. Vulnerability map Lampung Police Bodies

Destructive fishing practices cause damage to the marine ecosystem, especially coral reefs. Based on data from the Central Statistics Agency, from the year 2010 to 2015, the level of damage to the coral reefs of Lampung Province is quite high, as the following table:

Table 2. The extent and condition of coral reefs in Lampung Province 2012-2015

\begin{tabular}{|l|l|l|l|l|l|l|}
\hline \multirow{2}{*}{$\begin{array}{c}\text { Description of marine } \\
\text { resources }\end{array}$} & \multicolumn{7}{|c|}{ The extent and condition of coral reefs } \\
\cline { 2 - 7 } & $\mathbf{2 0 1 0}$ & $\mathbf{2 0 1 1}$ & $\mathbf{2 0 1 2}$ & $\mathbf{2 0 1 3}$ & $\mathbf{2 0 1 4}$ & \multicolumn{1}{|c|}{$\mathbf{2 0 1 5}$} \\
\hline Area (Ha) & 645.98 & 813.98 & 813980 & 670 & 670 & 2189.50 \\
\hline Good condition (\%) & 160.80 & 59.17 & 45 & 15.74 & 15.74 & 8.13 \\
\hline Moderate Condition (\%) & 238.18 & 24 & 32.50 & 59.45 & 59.45 & 20.67 \\
\hline Bad condition (\%) & 247 & 16.73 & 12.50 & 24.80 & 24.80 & 71.20 \\
\hline Not identified & - & 0.10 & 10 & 0.01 & 0.01 & - \\
\hline
\end{tabular}

Destructive fishing activities in Lampung Province generally use explosives that cause damage to coral reefs and the death of various types of fishes. Based on the results of the coral reef mapping conducted by the Department of Fisheries and Maritime Affairs of Lampung Province, the percentage of live coral cover as an indicator of damage to coral reefs, especially in Lampung Bay included in the criteria of evil to good. One area that is often targeted by destructive fishing is Tangkil Island. The percentage of rubble (rubble) due to the bombing on Tangkil Island reached 35\%. 


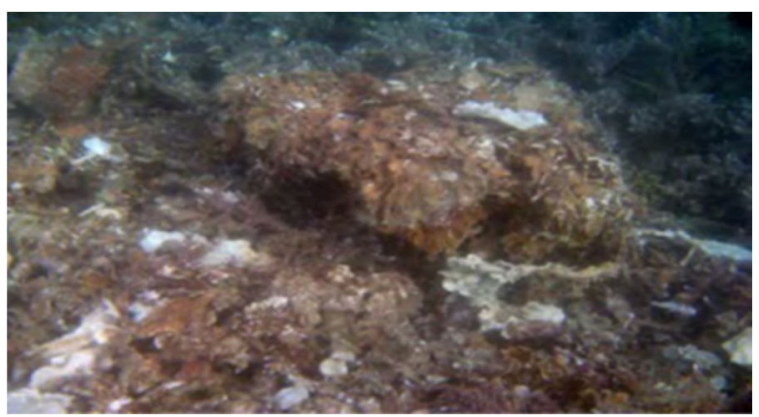

Fig 2. Coral reefs destroyed by bombing

Based on the description above, destructive fishing practices cause damage to the marine ecosystem. Therefore, overcoming harmful fishing practices is a must. The involvement of the community in tackling destructive fishing practices plays an important role, especially in terms of supervision. Involving the community in addressing destructive fishing needs to be done, bearing in mind the subject and object of the response are closely related to the existence of the city, mainly coastal communities. Also, coastal communities have a dependency on the availability of marine resources, especially fisheries. Furthermore, community involvement in the handling of destructive fishing, especially in terms of supervision, has been regulated in Article 67 of Law Number 31 the Year 2004 concerning Fisheries. Therefore, since 2007 the Ministry of Maritime Affairs and Fisheries has formed a Fishery Resources Supervisory Unit for the Supervision of Fisheries Resources, which is carrying out its duties involves the community by creating a community watch group (POKMASWAS). Community involvement in overcoming destructive fishing through the supervision of fisheries resources is essential because the community, especially those living on the coast are in direct contact with the sea.

Tackling destructive fishing based on community supervision is one form of community empowerment to play an active role and be directly involved in efforts to address damage to fishery resources. The existence of POKMASWAS provides direct benefits for the preservation of fisheries resources, especially in overcoming destructive fishing practices, which until now is still a strategic issue of the Indonesian Ministry of Maritime Affairs and Fisheries. The control of destructive fishing based on community supervision can also increase catches without damaging the sustainability of fisheries. Therefore, this article will discuss efforts to tackle community-based destructive fishing in Lampung Province. The problem considered is, what is the condition of the catastrophic fishing case in Lampung Province? How are efforts to tackle destructive fishing in Lampung Province? And what is the policy model for controlling community-based destructive fishing? Based on these problems, this article aims to find out and analyze efforts to overcome community-based destructive fishing in Lampung Province. 


\section{Methods}

The method that used to answer the problem in this study is the normative legal research method based on secondary data. Furthermore, the data obtained were analyzed qualitatively, and the results of the analysis deductively deduced..

\section{Results and Discussion}

\subsection{The Condition of Destructive Fishing Cases in Lampung Province}

State losses due to illegal fishing are increasing along with the rise of violations in the field of fisheries. Based on FAO data, Indonesia lost around Rp. 30 trillion per year due to illegal fishing. Destructive fishing is not only a threat to state revenues but also a threat to the sustainability of Indonesia's fisheries resources. Lampung Sea is an area prone to destructive fishing. The practice of the destructive fishery in Lampung Province generally carried out using bombs. Based on the author's search, from 2016 to 2019, there were 27 cases of destructive fishing that tried at the Class I A Tanjung Karang District Court as the following table:

Table 3. The case of destructive fishing in Lampung Province 2016-2019

\begin{tabular}{|c|c|c|}
\hline No & Case Number & Defendant \\
\hline 1. & 925/Pid.B/LH/2019/PN Tjk & Junaidi Bin Lukman Alm \\
\hline 2. & 923/Pid.B/LH/2019/PN Tjk & $\begin{array}{l}\text { 1) Sahrudin Bin Labunga } \\
\text { 2) Idi Amin Bin Hasan Basri }\end{array}$ \\
\hline 3. & 924/Pid.B/LH/2019/PN Tjk & M. Ayub Bin Hambali Alm \\
\hline 4. & 778/Pid.B/LH/2019/PN Tjk & Andi Saputra als Bejo Bin Rasmin \\
\hline 5. & 777/Pid.B/LH/2019/PN Tjk & Syamsudin als Acok Bin H. Rebang alm \\
\hline 6. & 776/Pid.B/LH/2019/PN Tjk & Abas Bin Sunarto \\
\hline 7. & 775/Pid.B/LH/2019/PN Tjk & Edi Yusup Bin M. Yusup \\
\hline 8. & 726/Pid.B/LH/2019/PN Tjk & Markuat Bin Matal alm \\
\hline 9. & 681/Pid.B/LH/2019/PN Tjk & Mustang Bin H. Juhere \\
\hline 10. & 590/Pid.B/LH/2019/PN Tjk & Jamal Bin Ibrohim \\
\hline 11. & 664/Pid.B/LH/2018/PN Tjk & Muhamad Rohman Bin Sarbani \\
\hline 12. & 598/Pid.B/LH/2018/PN Tjk & $\begin{array}{l}\text { 1) Sohni Junaedi Bin Hairudin alm, dkk } \\
\text { 2) Hairul Saleh als Iyung Bin Sanwani } \\
\end{array}$ \\
\hline 13. & 574/Pid.B/LH/2018/PN Tjk & Imron Bin Ito \\
\hline 14. & 546/Pid.B/LH/2018/PN Tjk & $\begin{array}{l}\text { Yohanes Hendriyanto atau Ahmad Ariyanto als } \\
\text { Anto Bin Markus }\end{array}$ \\
\hline 15. & 513/Pid.B/LH/2018/PN Tjk & Dedi Bin Suwandi \\
\hline 16. & 512/Pid.B/LH/2018/PN Tjk & Alimudin Bin Bedu \\
\hline 17. & 969/Pid.B/LH/2017/PN Tjk & Zainal Abidin Bin Nurung \\
\hline 18. & 896/Pid.B/LH/2017/PN Tjk & Sulaeman Bin H. Solong \\
\hline 19. & 697/Pid.B/LH/2017/PN Tjk & Hidayat als Dayat Bin Sulaiman \\
\hline 20. & 648/Pid.B/LH/2017/PN Tjk & Rustam als Udin Bin Hasan \\
\hline 21. & 598/Pid.Sus/LH/2017/PN Tjk & Samsu Alam Bin Sendiri \\
\hline 22. & 571/Pid.B/LH/2017/PN Tjk & Imron Bin Mustofa \\
\hline 23. & 335/Pid.B/LH/2017/PN Tjk & $\begin{array}{l}\text { 1) } \text { Mulyadi Bin Lide, dkk } \\
\text { 2) } \text { Adrianus Maju Bin Yosep Sawu } \\
\text { 3) David Bin Pagang } \\
\text { 4) Romli als Koyom Bin Meran } \\
\text { 5) Irpan Bin Lukman } \\
\text { 6) } \\
\text { Sigit Nugroho Bin Muji }\end{array}$ \\
\hline
\end{tabular}




\begin{tabular}{|l|l|l|}
\hline 24. & $281 /$ Pid.B/LH/2017/PN Tjk & Subandi Bin Arbani. \\
\hline 25. & $280 /$ Pid.B/LH/2017/PN Tjk & Jara Bin Lakajihi. \\
\hline 26. & $1242 /$ Pid.B/LH/2016/PN Tjk & Sarozi als Rozi Bin Tahwani \\
\hline 27. & $482 /$ Pid.Sus-LH/2016/PN Tjk & Muhammar als Amnas Bin Kalla \\
\hline
\end{tabular}

The practice of destructive fishing in Lampung Province generally charged with Article 1 paragraph (1) of the Emergency Law No. 12 of 1951 concerning Explosives. Out of a total of 27 cases, 26 cases of destructive fishing charged with Article 1 paragraph (1) of the Emergency Law Number 12 of 1951, and 1 case of the destructive fishery was charged with Article 84 paragraph (2) of Law Number 31 of 2004 as already amended by Law Number 45 of 2009 concerning Fisheries. Destructive fishing practices hurt the preservation of fishery resources in Lampung Province. Also, the quality of the catch with harmful fishing practices is undoubtedly different from the score with environmentally friendly tools. Destructive fishing practices in Lampung Province generally use explosives and also hurt the location of fishing, especially coral reefs.

Based on data from the Central Statistics Agency, damage to coral reefs in the Lampung Sea from 2010 to 2015 tends to increase (table 2). Furthermore, the rampant cases of destructive fishing show a low level of public awareness, especially fishers in Lampung Province. The rise of harmful fishing practices with explosives in Lampung Province will cause by several things, namely the ease of obtaining raw materials, simple assembly, shorter fishing time, and more catches. This made the community, especially fishers in Lampung Province, complete their fishing gear with explosives/bombs.

\subsection{Efforts to Overcome Destructive Fishing in Lampung Province}

Tackling destructive fishing is part of criminal policy, and attempts to protect fisheries resources. Efforts to tackle devastating fishing crime can broadly divide into two, namely the means of punishment and non-punishment. Countermeasures using penalties focus on eradication (repressive). Furthermore, overcoming criminal acts with non-penal means focuses on prevention (preventive). The factors causing destructive fishing include overlapping management authority, the conflict between fishers, strong patrol-client relations, raw materials for bombs and poisons quickly obtained, opportunities, or opportunities.

Efforts in overcoming destructive fishing in Lampung Province have so far tended to be a means of punishment or repressive action. Repressive actions against harmful fishing perpetrators are law enforcement efforts carried out in the form of prosecution, investigation, prosecution, and trial in court. Based on data from the Criminal Fishing Class I A Tanjung Karang District Court Information System data, there are 27 cases of destructive fishing that have permanent legal force (incraht). Of the 27 causes of the destructive fishery that were tried by the District Court of Class I A Tanjung Karang, 25 cases were sentenced to imprisonment, while two instances sentenced to prison and fines as the following table:

Table 4. A decision on the case of destructive fishing in Lampung Province

\begin{tabular}{|c|c|c|}
\hline No & Case Number & Verdict \\
\hline 1. & 925/Pid.B/LH/2019/PN Tjk & $\begin{array}{l}\text { imprisonment for } 2 \text { (two) years and } 6 \text { (six) } \\
\text { months }\end{array}$ \\
\hline 2. & 923/Pid.B/LH/2019/PN Tjk & imprisonment for 1 (one) year \\
\hline 3. & 924/Pid.B/LH/2019/PN Tjk & $\begin{array}{l}\text { imprisonment for } 3 \text { (three) years and } 10 \text { (ten) } \\
\text { months }\end{array}$ \\
\hline 4. & 778/Pid.B/LH/2019/PN Tjk & imprisonment for 2 (two) years \\
\hline 5. & 777/Pid.B/LH/2019/PN Tjk & imprisonment for 2 (two) years \\
\hline
\end{tabular}




\begin{tabular}{|c|c|c|}
\hline 6. & 776/Pid.B/LH/2019/PN Tjk & imprisonment for 1 (one) year \\
\hline 7. & 775/Pid.B/LH/2019/PN Tjk & imprisonment for 1 (one) year \\
\hline 8 . & 726/Pid.B/LH/2019/PN Tjk & imprisonment for 2 (two) years 6 (six) months \\
\hline 9. & 681/Pid.B/LH/2019/PN Tjk & imprisonment for 2 (two) years \\
\hline 10. & 590/Pid.B/LH/2019/PN Tjk & imprisonment for 2 (two) years \\
\hline 11. & 664/Pid.B/LH/2018/PN Tjk & imprisonment for 1 (one) year 11 (eleven) months \\
\hline 12. & 598/Pid.B/LH/2018/PN Tjk & imprisonment for 10 (ten) months \\
\hline 13. & 574/Pid.B/LH/2018/PN Tjk & $\begin{array}{l}\text { imprisonment for: } 2 \text { (two) years } 6 \text { (six) months } \\
\text { and a fine of Rp } 100,000,000 \text { (one hundred } \\
\text { million rupiahs), provided that if not paid, it } \\
\text { replaced with a sentence of } 6 \text { (six) months }\end{array}$ \\
\hline 14. & 546/Pid.B/LH/2018/PN Tjk & imprisonment for 2 (two) years \\
\hline 15. & 513/Pid.B/LH/2018/PN Tjk & imprisonment for 1 (one) years \\
\hline 16. & 512/Pid.B/LH/2018/PN Tjk & $\begin{array}{l}\text { imprisonment for } 1 \text { (one) year and } 4 \text { (four) } \\
\text { months }\end{array}$ \\
\hline 17. & 969/Pid.B/LH/2017/PN Tjk & $\begin{array}{l}\text { imprisonment for } 1 \text { (one) year and } 4 \text { (four) } \\
\text { months }\end{array}$ \\
\hline 18. & 896/Pid.B/LH/2017/PN Tjk & imprisonment for 1 (one) year 4 (four) months \\
\hline 19. & 697/Pid.B/LH/2017/PN Tjk & imprisonment for 8 (eight) months \\
\hline 20. & 648/Pid.B/LH/2017/PN Tjk & imprisonment for 8 (eight) months \\
\hline 21. & 598/Pid.Sus/LH/2017/PN Tjk & imprisonment for 1 (one) year 8 (eight) months \\
\hline 22. & 571/Pid.B/LH/2017/PN Tjk & imprisonment for 2 (two) years 6 (six) months \\
\hline 23. & 335/Pid.B/LH/2017/PN Tjk & imprisonment for 1 (one) year, 6 (six) months \\
\hline 24. & 281/Pid.B/LH/2017/PN Tjk & imprisonment for 2 (two) years \\
\hline 25. & 280/Pid.B/LH/2017/PN Tjk & imprisonment for 2 (two) years \\
\hline 26. & 1242/Pid.B/LH/2016/PN Tjk & imprisonment for 1 (one) year 4 (four) months \\
\hline 27. & 482/Pid.Sus-LH/2016/PN Tjk & $\begin{array}{l}\text { imprisonment for } 1 \text { (one) year and } 6 \text { (six) months } \\
\text { and a fine of Rp. } 5,000,000.00 \text { (five million } \\
\text { rupiahs) on the condition that the fine not be paid } \\
\text { to be replaced with imprisonment for } 6 \text { (six) } \\
\text { months }\end{array}$ \\
\hline
\end{tabular}

The practice of destructive fishing in Lampung Province generally carried out with explosives/fish bombs. Therefore most destructive fishing cases are prosecuted under Emergency Law No. 12 of 1951 concerning Explosives. Since 2016-2019 there have been 27 cases of destructive fishing, of which 25 cases have prosecuted under Emergency Law Number 12 of 1951, and 2 cases have prosecuted under Law Number 31 of 2004 concerning Fisheries. In terms of quantity, the sanctions in the Emergency Law Number 12 of 1951 are more severe than the penalties in the Law Number 31 of 2004. Based on the provisions of Article 1 Paragraph (1) of the Emergency Law Number 12 of 1951, someone who uses explosives punished with a death sentence or life imprisonment or a maximum prison sentence of twenty years.

Whereas, based on the provisions of Article 84 of Law Number 31 the Year 2004, the threat of sanctions for perpetrators of destructive fishing is a maximum of ten years imprisonment and a maximum fine of $\mathrm{Rp}$. 200,000,000 (two hundred million rupiahs).Furthermore, in Lampung Province, there is no Special Court for Fisheries. This condition causes the case of destructive fishing in Lampung Province to be tried by the District Court with a judge who has expertise in the environmental field. In contrast, for fisheries experts, it is limited to expert testimony. 


\subsection{The Community Oversight Destructive Fishing Countermeasure Policy Model}

Based on the provisions of Law No. 23 of 2014 concerning Regional Government, management of the coastal sea area, and small islands as far as 12 miles outside of oil and gas is the authority of the provincial government. Given the vast sea area of Lampung Province, a significant role and responsibility required from the Lampung Province regional government. However, sometimes there are limited infrastructure and human resources so that it becomes a significant obstacle in achieving optimal supervision, especially in the fisheries sector. So based on Article 67 of Law Number 31 the Year 2004 concerning Fisheries, the public can participate in fisheries supervision. Also, Law Number 27 of 2007 concerning Management of Coastal Areas and Small Islands mandates the government to recognize and respect community rights.

Furthermore, based on Article 9 paragraph (1) of the Minister of Maritime Affairs and Fisheries Regulation No. 40 / PERMEN-KP / 2014, community participation in monitoring management of coastal areas and small islands, among others, reports losses, suspected pollution, environmental hazards, and damage. In addition to providing opportunities for the community to oversee fisheries activities, community-based supervision can strengthen community togetherness in protecting the potential of their regional fisheries. Destructive fishing practices not only threaten the potential of fisheries but also cause environmental damage, especially marine ecosystems. Therefore, based on the provisions of Article 70 of Law Number 32 the Year 2009 concerning Protection and Management of Life Circles, the community has the same and broadest rights and opportunities to play an active role in the protection and management of the living environment. The part of the city is in the form of social supervision, giving advice, opinions, complaints, and delivering information/reports. Next, Article 3 letter g of Law Number 27 the Year 2007 concerning Management of Coastal Areas and Small Islands, that management of coastal areas and small islands based on community participation. Supervision of the control of the coastal regions and small islands by the community is done through complaints or submitting information to the authorities.

Cooperation in fisheries management has not been practical enough. During this time, participation in fisheries management tends to be competitive so that it causes the failure of fisheries management, which is marked by the rise of violations such as destructive fishing practices that cause environmental damage and poverty. Along with the emergence of the paradigm of marine development, various problems in the fisheries sector become a strategic issue to resolve. Overcoming different fisheries issues, especially destructive fishing in Lampung Province, requires a new model of policy that involves the participation of the community to achieve optimal monitoring performance. The monitoring model for controlling destructive fishing based on community supervision in Lampung Province divided into two, namely the means of punishment and non-punishment as described below:

\section{Penal Facilities}

Counter measures using penalties focus on eradication (repressive). The form of public supervision in the handling of destructive fishing through the means of punishment can be in the way of submitting reports to the authorities regarding the alleged practices of destructive fishing. Community-based supervision of destructive fisheries is essential to ensure optimal and sustainable fisheries management. Based on the Decree of the Minister of Maritime Affairs and Fisheries Number: KEP.58 / MEN / 2001 concerning Procedures for the Implementation of Community Oversight Systems in Management and Utilization of Marine and Fisheries Resources, in the form of fisheries supervisory community groups 
(POKMASWAS). In 2015 there were 81 POKMASWAS while in 2016 there were 64 POKMASWAS spread across ten Regencies / Cities in Lampung Province, as the following table:

Table 5. Lampung Province POKMASWAS 2015-2017

\begin{tabular}{|c|c|c|c|c|}
\hline \multirow{2}{*}{$\begin{array}{l}\text { Regency / } \\
\text { City }\end{array}$} & \multicolumn{3}{|c|}{ Number of Groups } & \multirow{2}{*}{$\begin{array}{l}\text { Coordination } \\
\text { Control Range }\end{array}$} \\
\hline & 2015 & 2016 & 2017 & \\
\hline $\begin{array}{c}\text { West } \\
\text { Lampung }\end{array}$ & 12 & 5 & - & \multirow{10}{*}{$\begin{array}{l}\text { SDKP Jakarta } \\
\text { Monitoring Base }\end{array}$} \\
\hline $\begin{array}{l}\text { Tulang } \\
\text { Bawang }\end{array}$ & 4 & 16 & - & \\
\hline Pesawaran & 9 & 10 & - & \\
\hline Pringsewu & 4 & 4 & - & \\
\hline $\begin{array}{c}\text { North } \\
\text { Lampung }\end{array}$ & 6 & 10 & & \\
\hline $\begin{array}{c}\text { East } \\
\text { Lampung }\end{array}$ & 5 & 6 & - & \\
\hline $\begin{array}{c}\text { South } \\
\text { Lampung }\end{array}$ & 10 & 3 & - & \\
\hline $\begin{array}{c}\text { Bandar } \\
\text { Lampung }\end{array}$ & 4 & 4 & - & \\
\hline $\begin{array}{l}\text { Way } \\
\text { Kanan }\end{array}$ & 23 & 2 & - & \\
\hline Mesuji & 4 & 4 & - & \\
\hline
\end{tabular}

The role of POKMASWAS in overcoming destructive fishing through penal means done through reporting or providing information about alleged harmful fishing practices to the nearest supervisory apparatus such as PPNS, Head of a fishing port, Head of Maritime Affairs and Fisheries Office, Navy and Satpol AIRUD nearby, and port quarantine officers. As table 5 above, Lampung Province is currently under the working area of the Jakarta Maritime and Fisheries Resources Control Base (PSDKP) with the Bid Supervision Unit. Furthermore, the recapitulation of the Jakarta SDKP Supervision Base fisheries is as follows:

Table 6. Recapitulation of the 2017 Jakarta PSDKP fisheries supervisor

\begin{tabular}{|c|c|c|c|}
\hline Employment status & Base / Station & Scope of Satwas & Amount \\
\hline Jend/dir PSDKP & 24 & 25 & 49 \\
\hline Offices & 4 & 19 & 23 \\
\hline
\end{tabular}

POKMASWAS can report suspected destructive fishing by Indonesian fishing vessels and foreign fishing vessels. The officer who received the report from POKMASWAS followed up by forwarding the information to PPNS, the Navy, SATPOL AIRUD, and fishery inspection vessels. Based on the POKMASWAS information, the authorities will then pursue and arrest the perpetrators of destructive fishing and then investigate and investigate. Based on the general explanation of the Regulation of the Minister of Maritime Affairs and Fisheries Number: KEP.58 / MEN / 2001, in conducting follow-up operations on violations, the Provincial Fisheries Service coordinates with fisheries supervision officers (Indonesian Navy, Indonesian National Police, Indonesian National Police, PPNS, and BAKAMLA). 


\section{Non-Penal Facilities}

Tackling destructive fishing with non-penal means focuses on prevention (preventive). The handling of the destructive fishery so far has prioritized law enforcement with a fisheries criminal act approach. It has not been able to solve problems in the fishery sector, one of which is destructive fishing practices. This condition caused by various fisheries supervision limitations such as facilities, human resources, and budget. The fisheries supervisory facilities and human resources in Lampung Province are currently in the following chart:

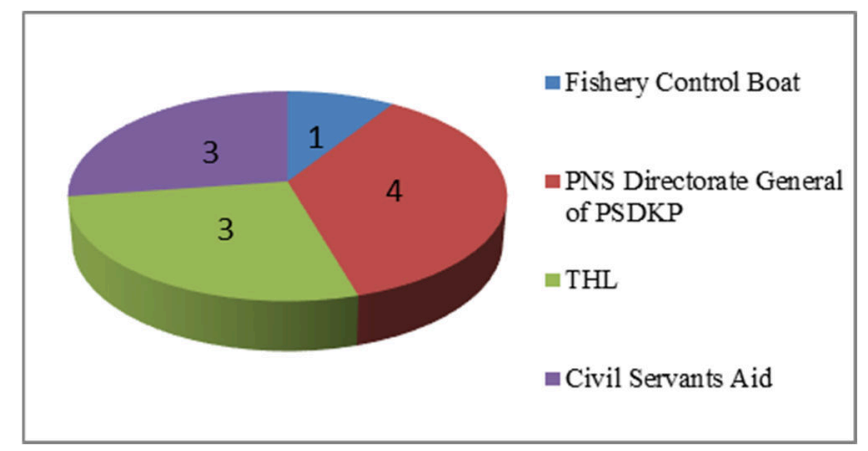

Fig 2. Chart 1. 2019 Lampung Province fisheries supervisors facilities and human resources

The fishery control vessel in Lampung Province at the moment is Napoleon 014, with a size of 12 meters, which located at the Pesawaran SDKP Satwas. The human resources of SDK Pesawaran Satwas numbered ten people. On the other hand, the SDK SDK Peswas Satwas has a relatively wide working area of 15 districts/cities in Lampung Province. To means that fishery's supervisory facilities and human resources in Lampung Province are not yet well established when compared to their working area. Therefore, community participation in fisheries supervision has a significant bearing given the various limitations of human resources and the currently limited allocation of fisheries supervision funding. Community oversight in the handling of destructive fishing through non-penal means carried out through coordination and participation in a variety of supervisory programs related agencies such as PSDKP, Navy, Police, PPNS, and BAKAMLA. These programs can be in the form of planning for the prevention of destructive fishing, surveillance operations for fisheries resources, and monitoring fishing vessel compliance. Realize optimal community participation in fisheries supervision, and it is necessary to improve the monitoring facilities and infrastructure, including surveillance posts, speed boats, communication tools, and other surveillance equipment.

Supervision of community-based destructive fishing carried out by distributing responsibilities from the Provincial Government of Lampung to local communities. Local communities have a substantial control role in the prevention of harmful fishing practices in Lampung Province. Also, community involvement in fisheries supervision can reduce community involvement in illegal transshipment on the high seas. Therefore, the Lampung Provincial Government's policy must provide opportunities for local communities to get involved in fisheries surveillance to prevent destructive fishing practices. Furthermore, the Lampung Provincial government policy must prioritize the development of SISMASWAS, which carried out through the empowerment of POKMASWAS. Supervision by empowering 
the community can help in overcoming, especially the prevention of destructive fishing practices in Lampung Province. The community-based supervision scheme, namely:

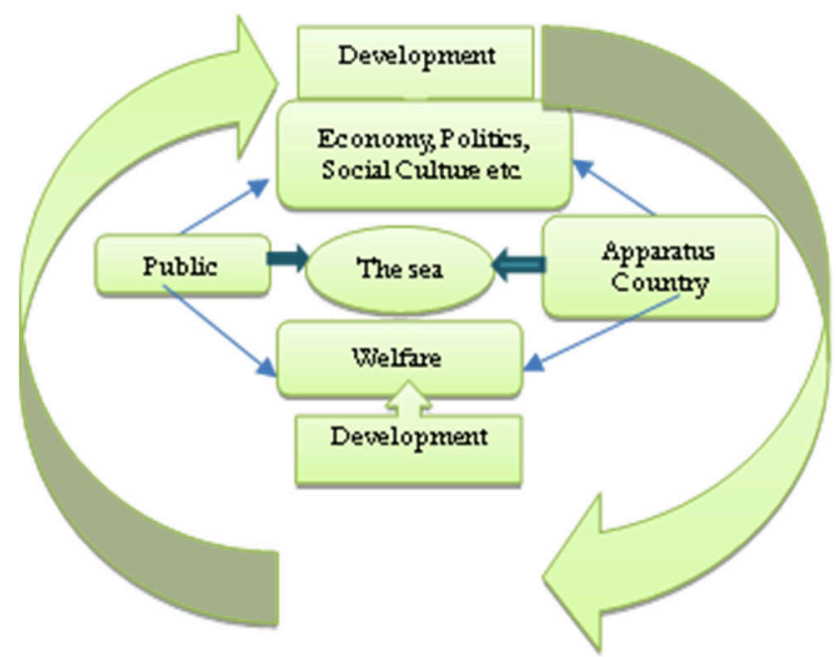

Fig 3. Community-based supervision schemes

Considering the various limitations in overcoming destructive fishing practices that have caused the development of the fisheries sector not being maximized, community-based supervision is a solution in overcoming destructive fishing. Community participation in overcoming destructive fishing places more emphasis on non-penal or prevention efforts. It is due to various problems, including the low sanctions given compared to the losses incurred. Supervision of community-based destructive fishing practices through non-penal means carried out through coordination and community involvement in every marine and fisheries supervision program.

\section{Conclusion and Recommendation}

The practice of destructive fishing in the Province generally carried out using bombs. From 2016 to 2019, there were 27 cases of the destructive fishery that tried at the Class A District Court of Tanjung Karang. The practice of destructive fishing in Lampung Province generally charged with Emergency Law No. 12 of 1951 concerning Explosives. Efforts to tackle destructive fishing in Lampung Province are currently more inclined to the means of punishment or repressive actions. Of the 27 causes of the destructive fishery that were tried by the Tanjung Karang Class I District Court, 25 cases were sentenced to imprisonment, while two instances sentenced to prison and fines. Considering various obstacles in achieving optimal fisheries supervision, I was a new model.

It needed that involves the community in tackling destructive fishing practices, especially in Lampung Province, namely the prevention of destructive fishing based on community supervision. The handling of the destructive fishery based on community surveillance divided into two, namely the means of punishment and the means of non-punishment. Community oversight in the processing of destructive fishing through the means of discipline in the form 
of submission of reports to the authorities regarding the alleged practices of destructive fishing. Furthermore, community supervision in overcoming destructive fishing through nonpenal means carried out through coordination and community participation in various programs of control of related agencies such as PSDKP, Navy, Police, PPNS, and BAKAMLA.

Based on these conclusions, it recommended that the Lampung provincial government address the practice of destructive fishing by prioritizing community participation, especially in terms of supervision.

\section{References}

[1] Alains, A. Muluk, dkk. (2009). Pengelolaan Sumberdaya Perikanan Berbasis Masyarakat (PSPBM) Melalui Model Co-Management Perikanan. Jurnal Ekonomi Pembangunan, Vol. 10, (2), pp. 172-173.

[2] Asri, Muh, dkk. (2019). Praktik Perikanan Destructive (Studi Kasus Pada Taman Nasional Taka Boberate). Sodality:Jurnal Sosiologi Pedesaan, Vol. 7, (1), p. 27.

[3] Dano, Tri Yulian, dkk. (2015). Upaya Penanggulangan Tindak Pidana Penangkapan Ikan Di Perairan Sumatera Barat Oleh Polisi Perarian Polda Sumatera Barat," Jurnal Faculty of Law Bung Hatta University, Vol. 6, (1), p. 8.

[4] DKP Provinsi Lampung dan PT. Taram. (2007).Pemetaan Terumbu Karang Di Teluk Lampung. Bandar Lampung: PT. Taram.

[5] Hadiwinata, Ahmad Marthin. (2015). Analisis Hukum Terhadap Pengaturan Pengelolaan Perikanan Berbasis Masyarakat Di Indonesia. Jurnal Hukum Lingkungan, Vol. 2, (1),p. 16.

[6] K, Septiani, dan M. Kemal Dermawan. (2016). Implementasi Kemitraan Dalam Pemolisian Komunitas Untuk Pencegahan Praktik Destructive Fishing (Studi Kasus Perairan Laut Maluku Utara). Indonesian Journal Of Criminology, Vol. 1 (1), p.53.

[7] Keputusan Menteri Kelautan dan Perikanan No. KEP.58/MEN/2001 tentang Tata Cara Pelaksanaan Sistem Pengawasan Masyarakat Dalam Pengelolaan Dan Pemanfaatan Sumberdaya Kelautan dan Perikanan. 2001. Jakarta.

[8] Mcmanus, Jhon W. (1997). Effect of Some Destructive Fishing Methods on Coral Cover and Potential Rates of Recovery. Environmental Management, Vol. 21, (1), p. 69.

[9] Naim, Armain. (2010). Pengawasan Sumberdaya Perikanan Dalam Penanganan Illegal Fishing Di Perairan Provinsi Maluku Utara. Jurnal Ilmiah Agribisnis dan Perikanan, Vol. 3, (2), p. 9.

[10] Nurdin, Nurliah. (2010). Kajian Efektifitas Kebijakan Pada Kasus Destructive Fishing Menuju Pengelolaan Wilayah Pesisir Berbasis Masyarakat Pada Pulau-Pulau Kecil (Studi Pada Pulau Karanrang Kabupaten Pangkep Sulawesi Selatan),Jurnal Bumi Lestari, Vol. 10, (2), p. 245.

[11] Pariwono, John. I. (1999).Kondisi Oseanografi Perairan Pesisir Lampung. Jakarta: BAPPENAS.

[12] Peraturan Menteri Kelautan dan Perikanan No 40/PERMEN-KP/2014 tentang Peran Serta Dan Pemberdayaan Masyarakat Dalam Pengelolaan Wilayah Pesisir Dan Pulau-Pulau Kecil. 2014. Jakarta.

[13] Rifa'i, Eddy, dan Khaidir Anwar. (2014). Politik Hukum Penanggulangan Tindak Pidana Perikanan. Jurnal Media Hukum, Vol. 21, (2), p. 282.

[14] Risnain, Muh.(2017). Rekonsepsi Model Pencegahan Dan Pemberantasan Illegal Fishing Di Indonesia," Padjajaran Jurnal Ilmu Hukum, Vol. 4, (2), p. 380.

[15] Salsabila, A. Pramesti. (2018). Pengoptimalan Satgas 115 Dengan Model Koordinasi Satgas Pusat Dan Daerah Sebagai Bentuk Pencegahan Illegal Transhipment Di Indonesia. Lex Scientia Law Review, Vol. 2, (1), p. 16.

[16] Saputra, Dinda. (2018). Pelaksanaan Fungi Pengawasan Ditpolair Polda Lampung Terhadap Kejahatan Menangkap Ikan Dengan Bahan Peledak. Skripsi. Lampung: Fakultas Hukum Universitas Lampung. 
[17] Shafira, Maya. (2017). Nonpenal Effort In Addressing Illegal Fishing In The Lampung Province. Proceeding of International Conference 2nd SHIELD 2017 Bandar Lampung, September 18-20th 2017.

[18] Sihombing, Y. Hamonangan. (2017). Optimalisasi Hukum Laut Nasional Untuk Pengembangan Potensi Sumber Daya Perikanan Di Indonesia. Jurnal Hukum Lingkungan, Vol. 3, (2), p. 99.

[19] Strategic Plan of the Director-General of Maritime and Fisheries Resources Supervision 20152019.

[20] Suawa, Youdy R, dkk. (2019). Effectivennes of Vessel Sinking Legal Action in the Area of Marine and Fisheries Resources Monitoring Base of Bitung, North Sulawesi. Journal of Aquatic Science \& Management, Vol. 7, (1), p. 13-14.

[21] Tiaraputri, Adi,dan Ledy Diana. (2017). Peran Serta Masyarakat Dalam Pengawasan Sumber Daya Kelautan Di Kabupaten Bengkalis Dalam Perspektif Hukum Laut Nasional. Prosiding 2thCelscitechUMRII, Vol. 2, September 2017.

[22] Undang-Undang Darurat Nomor 12 Tahun 1951 tentang Bahan Peledak. 1951. Jakarta.

[23] Undang-Undang Nomor 23 Tahun 2014 tentang Pemerintahan Daerah. 2014. Jakarta.

[24] Undang-Undang Nomor 27 Tahun 2007 tentang Pengelolaan Wilayah Pesisir dan Pulau-Pulau Kecil. 2007. Jakarta.

[25] Undang-Undang Nomor 31 Tahun 2004 tentang Perikanan. 2004. Jakarta.

[26] Undang-Undang Nomor 32 Tahun 2009 tentang Perlindungan dan Pengelolaan Lingkungan Hidup. 2009. Jakarta.

[27] Undang-Undang Nomor 45 Tahun 2009 tentang Perikanan. 2009. Jakarta.

[28] Yuliana, Ernik. (2012). Pengaruh Karakteristik dan Persepsi Terhadap Tingkat Partisipasi Anggota Dalam Kelompok Masyarakat Pengawas (Pokmaswas) Sumberdaya Kelautan dan Perikanan. Jurnal Bumi Lestari, Vol. 12 (2), pp. 251-251. 